\title{
Temperature-Dependent Alterations in Metabolic Enzymes and Proteins of three Ecophysiologically Different Species of Earthworms
}

\author{
G.Tripathi ${ }^{*}$, N.Kachhwaha, I. Dabi and N. Bandooni \\ Department of Zoology; J. N. V. University; Jodhpur; 342001 - India
}

\begin{abstract}
The effects of varying temperatures $\left(12-44^{\circ} \mathrm{C}\right)$ on the specific activity of cytoplasmic malate dehydrogenase $((\mathrm{cMDH})$, mitochondrial malate dehydrogenase $(\mathrm{mMDH})$ and lactate dehydrogenase $(\mathrm{LDH})$ of some earthworms (Metaphire posthuma, Perionyx sansibaricus and Lampito mauritii) were studied. The effects of different temperatures on supernatant and mitochondrial protein contents were also investigated. The specific activities of $c M D H, m M D H$ and LDH of the earthworms decreased gradually as a function of increasing temperature from 12 to $44^{\circ} \mathrm{C}$. Higher metabolic energy was needed to maintain the activity at low temperatures. Hence, the earthworms showed increased enzyme specific activity at low temperatures. However, the protein content increased upto $28^{\circ} \mathrm{C}$. Afterwards, with the increase in the temperature from 28 to $42{ }^{\circ} \mathrm{C}$, the proteins in the earthworms showed a significant decrease. The temperature-associated changes in the protein content could be explained by the fact that protein synthesizing capacity was hampered above and below the optimum temperature range. The most pronounced effects of varying temperatures were on $\mathrm{P}$. sansibaricus. It might be due to the epigeic nature of the earthworm species. Then minimum effect was on the endogeic earthworm M. posthuma. Virtually, the differences in the enzymes physiology were associated with the differences in the ecological categories of the earthworms. This clearly demonstrate a possible link between the physiology and ecology at aerobic (cMDH, mMDH) and anaerobic (LDH) levels in the tropical earthworms.
\end{abstract}

Key words: Enzymes, proteins, earthworms, temperatures

\section{INTRODUCTION}

Temperature has a profound effect on the metabolism of organisms. Depending on the species, earthworms possess varying temperature optima and tolerances and even adopt to cope with temperature extremes. They may show long-term responses to chronic temperature change both in laboratory and in natural habitat. A very limited numbers of metabolic enzymes of oligochaetes have been studied to demonstrate the temperature effects. Pomert and Zarrow (1936) showed the effect of temperature on the respiration of the earthworm. Saroja (1961) documented seasonal acclimatization of oxygen consumption to temperature in tropical earthworm Megascolex mauritii. Temperature may be a factor of primary importance in determining the composition and structure of earthworm communities (Lavelle, 1983; Lavelle et al., 1989). Hazel (1995) described

\footnotetext{
*Author for correspondence: drgst@ rediffmail.com
} 
thermal adaptation in biological membranes. Temperature affects the lipid composition of the earthworm Lumbricus rubellus and Eisenia nordenskioeldi (Petersen and Holmstrup, 2000). It appears to be the most important environmental variable influencing the growth, metabolism and biology of earthworms. Tripathi and Bhardwaj (2004a) suggested that the earthworm population mainly decreased with the increase in soil temperature. Tripathi and Bhardwaj (2004b) made a comparative assessment of biomass growth of Eisenia fetida and Lampito mauritii at different temperatures. The biomass of both the species of earthworms varied significantly with the changes in temperature. The optimum temperatures for $E$. fetida and L. mauritii were 25 and $30^{\circ} \mathrm{C}$, respectively.

Different earthworms have their own optimum temperature (Lee, 1985). A Siberian species, Eisenia nordenskioeldi (Eisen) lives in the areas with permafrost and has developed freezetolerance mechanism for survival in the extreme habitat, where more than one summer season is required to complete a lifecycle (Mazantzeva, 1985; Holmstrup and Petersen, 1997). Holmstrup et al. (1999) reported that E. nordenskioeldi synthesized and accumulated glucose as an immediate response to ice formation in extracellular body fluids. Glucose accumulation has also been detected in the freeze-intolerant $L$. rubellus upon freezing but at much lower concentrations. Depending on the species, earthworms possess varying temperature optima and tolerances as well as different strategies for coping with the environmental temperatures extremes (Holmstrup and Zachariassen, 1996). Invertebrates, microbes and higher organisms have been shown to respond to temperature changes by adjusting the composition of membrane phospholipid fatty acids (Hazel, 1995). The earthworm, Lumbricus terrestris produces carbonic acid at constant rate when is exposed to temperatures between 10 and $22^{\circ} \mathrm{C}$. It can compensate its rates of oxygen consumption between 5 and $15^{\circ} \mathrm{C}$ after a two week acclimation to these temperatures (Fitzpatrick et al., 1987). The rate of respiration of earthworms is very sensitive to the environmental temperature. The respiration rate increases as the body temperature rises. The temperature effect on animal activity related to aerobic metabolism is very common. Oxygen consumption has been accepted as an indirect measurement for aerobic metabolic rate (Arnould et al., 2001). Therefore, their thermal acclimatization is in relation with their oxygen consumption (Magnum, 1978). Aerobic metabolic rate of most earthworms increases two times when their body temperature increases by $10^{\circ} \mathrm{C}$ (Well, 1980; Lee, 1985; Eshky et al., 1996). Aestivating earthworms showed remarkable reductions in oxygen uptake and hence, in their metabolism (Abe, 1985). Earthworms in tropical areas generally have higher respiration rates than those in temperate regions (Saroja, 1961; Abe, 1985).

Earthworms live in different strata of oxygen availability in the soil such as top soil (Perionyx sansibaricus) and sub soil (Metaphire posthuma) and deep soil (Lampito mauritii). The characteristics of cellular activities in the context of the environmental and lifestyle constraints have been studied in a very few invertebrates (Pörtner, 2002). These ecological divergences in the lifestyle of earthworms provide an excellent platform to explore possible links between the physiology and ecology at aerobic and anaerobic level. Most of the earthworms remain active over a wide thermal range because they exhibit compensatory changes which allow them to have constancy in energy output after the acclimination to different temperatures. Although much is known about the temperature biology of earthworms, it is not known to what extent earthworms employ compensatory changes in enzymatic capacities after exposure to low temperature (Fan et al. 2001).

Malate dehydrogenase (MDH, 1-malate: $\mathrm{NAD}^{+}-$ oxidoreductase, EC 1.1.1.37) catalyzes the interconversion of oxaloacetate to malate and exists in two distinct isozymic forms, i.e., cytoplasmic (cMDH) and mitochondrial (mMDH). The cMDH takes part on the cytoplasmic side of the shuttle and provides means of transporting NADH equivalents, in the form of malate, across the mitochondrial membrane. Malate is oxidized into oxaloacetate by $\mathrm{mMDH}$ of the tricarboxylic acid cycle inside mitochondria. It leads to the generation of proton $\left(\mathrm{H}^{+}\right)$, which is subsequently driven up by the respiratory chain for the production of energy. Lactate dehydrogenase $\left(\mathrm{LDH}, \alpha\right.$ lactate: $\mathrm{NAD}^{+}$- oxido reductase, EC 1.1.1.27) is an important metabolic enzyme which catalyzes the interconversion of pyruvate to lactate in anaerobic glycolysis. It has multiple molecular forms and is involved in the anaerobic energy 
production, NADH recycling and gluconeogenesis. Since the enzymes allow specific reactions to proceed and collectively constitute the metabolism of a living cell, the study on temperature associated changes in metabolic dehydrogenases may be an interesting and useful aspect for physiology of earthworms.

\section{MATERIALS AND METHODS}

\section{Earthworm}

The three species of earthworm namely, Perionyx sansibaricus, Metaphire posthuma and Lampito mauritii were selected as experimental animals. The body lengths of mature individuals of $P$. sansibaricus, M. posthuma, and L. mauritii were $98 \pm 15 \mathrm{~mm}, 102 \pm 33 \mathrm{~mm}$ and $225 \pm 64 \mathrm{~mm}$, respectively. These earthworms represented three different categories of habitats. P. sansibaricus is a surface or litter dweller (epigeics). M. posthuma is a minerals soil dweller (endogeic). L. mauritii is deep burrower (anecic). The earthworms of each species were divided into five groups for the study of thermal effects. These groups were maintained separately at different temperatures, i.e., 12, 20, 28,36 and $44^{\circ} \mathrm{C}$ for two weeks. There were six replications $(\mathrm{n}=6)$ for each acclimation temperature.

\section{Chemicals}

Bovine serum albumin, Folin-Ciocalteau reagent, $\beta$-NADH, oxaloacetate, sodium pyruvate and other chemicals were procured either from Sisco Research Laboratory (India) or Sigma Chemical Company (USA). The double-distilled water was used for the preparation of reagents. Substrates such as oxaloacetate, sodium pyruvate and $\beta$ NADH were freshly prepared.

\section{Preparation of Enzyme Fraction}

About 24-h prior to use, the worms were rinsed in the water and kept on damp filter paper at $25^{\circ} \mathrm{C}$ to allow the voiding of gut contents. A $10 \%$ homogenate $(\mathrm{w} / \mathrm{v})$ was prepared in ice cold buffers using a Potter- Elvehjem homogenizer fitted with a teflon pestle. The homogenates were centrifuged at $700 \mathrm{~g}$ for $10 \mathrm{~min}$ in a high speed refrigerate centrifuge (Remi, cooling centrifuge) to remove the cell debris. The supernatant was decanted and centrifuged at $12,000 \mathrm{~g}$ for $15 \mathrm{~min}$ to get the mitochondrial pellet. The resulting supernatant was taken as cytoplasmic fraction for the assay of cytoplasmic malate dehydrogenase and lactate dehydrogenase. The mitochondrial pellet was washed in $0.1 \mathrm{M}$ sodium phosphate buffer $(p \mathrm{H} 7.4)$ and centrifuged at 12,100g for $10 \mathrm{~min}$. Finally, the mitochondrial pellet was suspended in the above buffer and homogenized at high speed. The homogenized suspension was recentrifuged at $21,000 \mathrm{~g}$ for $15 \mathrm{~min}$ to remove the particulate matter. The resulting supernatant was taken as mitochondrial fraction for the assay of mitochondrial malate dehydrogenase $(\mathrm{mMDH})$. All the procedures were carried out at $0-4^{\circ} \mathrm{C}$. The procedure employed for the subcellular fractionation and extraction of the mitochondrial enzyme was based on Foster and Moon (1986).

\section{Enzyme assay}

The procedure of Schwantes and Schwantes (1982) was adopted for the assay of malate dehydrogenase. The activity was measured in a medium containing $100 \mathrm{mM}$ sodium phosphate buffer ( $p \mathrm{H}$ 7.4), $0.4 \mathrm{mM}$ oxaloacetate and $0.12 \mathrm{mM}$ $\mathrm{NADH}$. The total volume of reaction mixture was $3.0 \mathrm{ml}$. The optimum concentrations of oxaloacetate, NADH and enzyme were used. The reaction was initiated by the addition of oxaloacetate. The procedure of Childress and Somero (1990) was adopted for the assay of lactate dehydrogenase with little modification. LDH was assayed in a medium containing $80 \mathrm{mM}$ Tris- $\mathrm{HCl}$ buffer $(\mathrm{pH} 7.5), 2 \mathrm{mM}$ pyruvate and $0.15 \mathrm{mM}$ NADH in a total volume of $3.0 \mathrm{ml}$. The reaction was initiated by the addition of pyruvate. The change in absorbance was recorded at $340 \mathrm{~nm}$ $(\mathrm{EmM}=6.22)$ at $10 \mathrm{~s}$ intervals in a Cintra 5 , UVVIS spectrophotometer. The readings were taken against a blank. The absorbance between 30s-40s after the start of the reaction was used to calculate the enzyme activity. Different enzymes were assayed at $24 \pm 2^{\circ} \mathrm{C}$. One unit of enzyme activity was defined as the amount of enzyme catalyzing the reduction or oxidation of one $\mu$ mole of coenzyme per minute under the above-specified conditions. The specific activitywas expressed as units $\mathrm{x} \mathrm{mg}$ protein ${ }^{-1}$. The activity was calculated using the molar extinction coefficient for NADH of $6.22 \times 10^{3} \mathrm{~cm}^{2} \mathrm{~mol}^{-1}$ at $340 \mathrm{~nm}$ (Horecker and Kornberg, 1948). 


\section{Protein estimation}

The protein contents of both supernatant and mitochondrial fractions were determined by FolinCiocalteau method (Lowry et al., 1951). The standard linear plot of protein was prepared by using bovine serum albumin (BSA). The total protein content was expressed as $\mathrm{mg} \mathrm{x} \mathrm{g}^{-1}$ wet wt. of the tissue.

\section{Statistical analysis}

One and two way analysis of variance (ANOVA) and Duncan's multiple range test (DMRT) (alpha level=0.05) were employed to determine the variations due to changes in different variables and their interactions.

\section{RESULTS}

Cytoplasmic malate dehydrogenase (cMDH)

One way ANOVA indicated that the specific activity of cMDH varied significantly $(\mathrm{P}<0.001)$ as a function of increasing temperature from 12 to $44^{\circ} \mathrm{C}$ in P. sansibaricus and L. mauritii. However, in $M$. posthuma, the specific activity did not vary significantly $(\mathrm{P}<0.001)$ with respect to the variations in sorrounding temperature. The DMRT indicated that the $\mathrm{cMDH}$ specific activity at $28^{\circ} \mathrm{C}$ was significantly different from that at $12^{\circ} \mathrm{C}$ in all the three earthworm species. The changes in the sorrounding temperature from 12 to $44^{\circ} \mathrm{C}$ gradually and significantly decreased the specific activity of cMDH of the earthworms (Fig. 1). The decrease in the specific activity of $M$. posthuma at $44^{\circ} \mathrm{C}$ was approximately $40 \%$ of the specific activity at $12^{\circ} \mathrm{C}$. P. sansibaricus at $44^{\circ} \mathrm{C}$ showed the decline of $62 \%$ in cMDH specific activity. At $44^{\circ} \mathrm{C}$, the reduction of $54 \%$ was found in specific activity of $\mathrm{cMDH}$ of $L$. mauritii. It indicated that the metabolism of earthworms was very sensitive to the temperature. Therefore, to maintain the vital activities in low temperatures, it needed more metabolic energy, which was facilitated by higher specific activity of the metabolic enzymes.

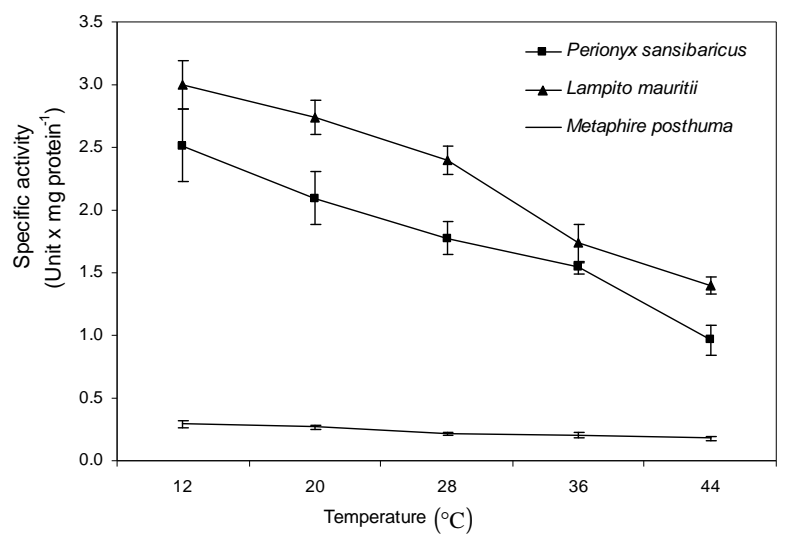

Figure 1 - Effects of temperature on specific activity of cytoplasmic malate dehydrogenase $(\mathrm{cMDH})$ of different species of earthworms.

\section{Mitochondrial malate dehydrogenase (mMDH)} The ANOVA showed that the increase in sorrounding temperature produced statistically significant $(\mathrm{P}<0.001)$ changes in the specific activity of mMDH of the earthworm species. The variations in the sorrounding temperature from 12 to $44^{\circ} \mathrm{C}$ gradually decreased the $\mathrm{mMDH}$ specific activity. The specific activity of $\mathrm{mMDH}$ of $M$. posthuma showed $48 \%$ reduction with the increasing temperature from 12 to $44^{\circ} \mathrm{C}$ (Fig. 2).
The decrease of $68 \%$ was observed in specific activity of $P$. sansibaricus (Fig. 2). About $69 \%$ decline in the specific activity of mMDH was observed in L. mauritii (Fig. 2). The mMDH specific activity was high at low temperature, which decreased with the increase in sorrounding temperatures. The increase in $\mathrm{mMDH}$ activity enhances the efficiency of TCA cycle to produce more metabolic energy to maintain its vital activities at low temperatures. 


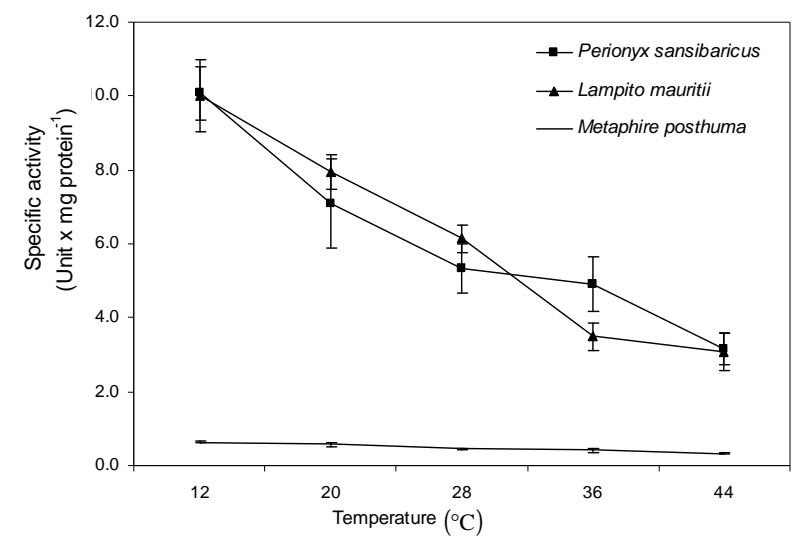

Figure 2 - Effects of temperature on specific activity of mitochondrial malate malate dehydrogenase (mMDH) of different species of earthworms.

\section{Lactate dehydrogenase (LDH)}

The specific activity of LDH of the three earthworm species changed significantly $(\mathrm{P}<0.001)$ with respect to increasing temperature from 12 to $44^{\circ} \mathrm{C}$. The $\mathrm{LDH}$ specific activity at $20^{\circ} \mathrm{C}$ was statistically different from that at $12^{\circ} \mathrm{C}$. The increase in ambient temperature gradually decreased the specific activity of lactate dehydrogenase of the earthworms. The reduction in LDH specific activity was approximately 2.8 times at $44^{\circ} \mathrm{C}$ as compared to the specific activity at $12^{\circ} \mathrm{C}$ in $M$. posthuma (Fig. 3). The maximum increase in the specific activity of LDH of $P$. sansibaricus at $12^{\circ} \mathrm{C}$ was approximately 3.7 times as compared to the specific activity of $\mathrm{LDH}$ at $44^{\circ} \mathrm{C}$ (Fig. 3). The maximum reduction in specific activity of $\mathrm{LDH}$ in L. mauritii at $44^{\circ} \mathrm{C}$ was about 2.7 times as compared to the $\mathrm{LDH}$ specific activity at $12^{\circ} \mathrm{C}$ (Fig. 3). The maximum elevation in the enzyme specific activity of LDH indicated that the earthworm surviving at different temperatures exhibited different degree of metabolic activities. Therefore, to maintain high metabolic activity at low temperature, there was a need of more energy requirement, which was facilitated by higher specific activity of anaerobic enzyme (LDH).

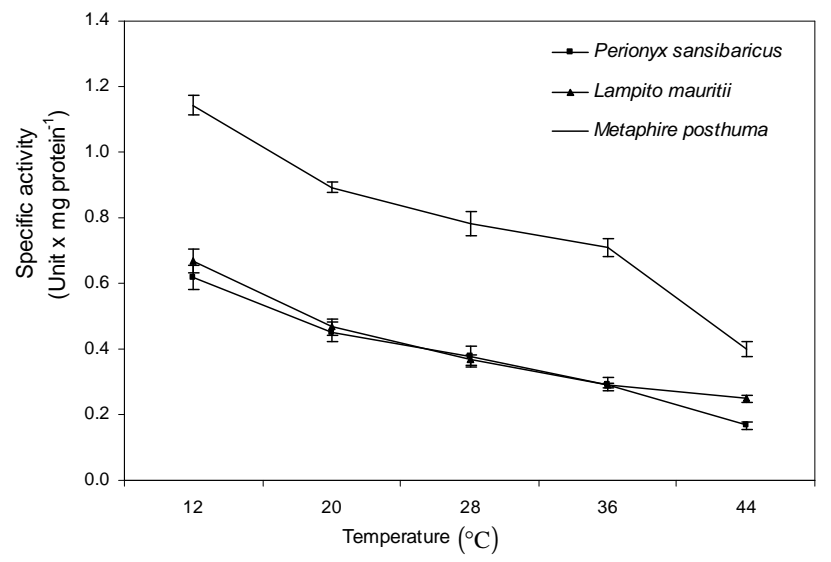

Figure 3 - Effects of temperature on specific activity of lactate dehydrogenase (LDH) of different species of earthworms

\section{Supernatant protein}

The ANOVA showed that the supernatant protein content varied significantly $(\mathrm{P}<0.001)$ as a function of changing temperature from 12 to $44^{\circ} \mathrm{C}$ in the earthworm species. The increase in the sorrounding temperature from 12 to $28^{\circ} \mathrm{C}$ gradually increased the supernatant protein content of the earthworms. However, further increase from 
$28-44^{\circ} \mathrm{C}$ reduced the supernatant protein content of all the earthworm species (Fig. 4). The increase in supernatant protein content from 12 to $28^{\circ} \mathrm{C}$ might be inducing the protein synthesizing capacity of the earthworms. The increased metabolic activities raised the protein synthesis. However, further increase of temperature from 28 to $44^{\circ} \mathrm{C}$ decreased the protein level of body as the protein synthesis might have hampered above the optimum temperature range.

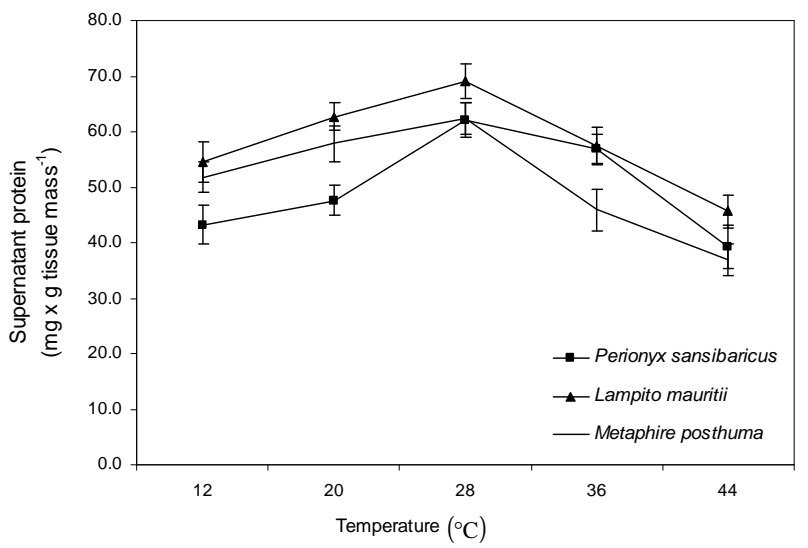

Figure 4 - Effects of temperature on supernatant protein content of different species of earthworms.

\section{Mitochondrial protein}

The protein content in the mitochondrial fraction of three earthworms changed significantly $(\mathrm{P}<0.001)$ with respect to increasing the sorrounding temperature from 12 to $44^{\circ} \mathrm{C}$, as shown by one-way ANOVA. However, DMRT indicated that the values of protein at $44^{\circ} \mathrm{C}$ were statistically different from that at $12^{\circ} \mathrm{C}$. The mitochondrial protein content showed increase with the increase from 12 to $28^{\circ} \mathrm{C}$; it declined with the subsequent increase of temperature from 28 to $44^{\circ} \mathrm{C}$ in M. posthuma and L. mauritii (Fig. 5). In the epigeic earthworm, $P$. sansibaricus, the mitochondrial protein showed induction with the increase in temperature from 12 to $36^{\circ} \mathrm{C}$. The further increase of temperature from 36 to $44^{\circ} \mathrm{C}$ reduced the mitochondrial protein content of this earthworm (Fig. 5). The concentration of mitochondrial protein increased with the temperature. Perhaps, the optimum temperatures enhanced the rate of protein synthesis. However, further increase in temperature might have disabled the protein synthesizing capacity of the body. The mitochondrial protein of $P$. sansibaricus increased from 12 to $36^{\circ} \mathrm{C}$. This epigeic earthworm might possess different temperature optima and tolerance level as strategy for coping with the different temperatures.

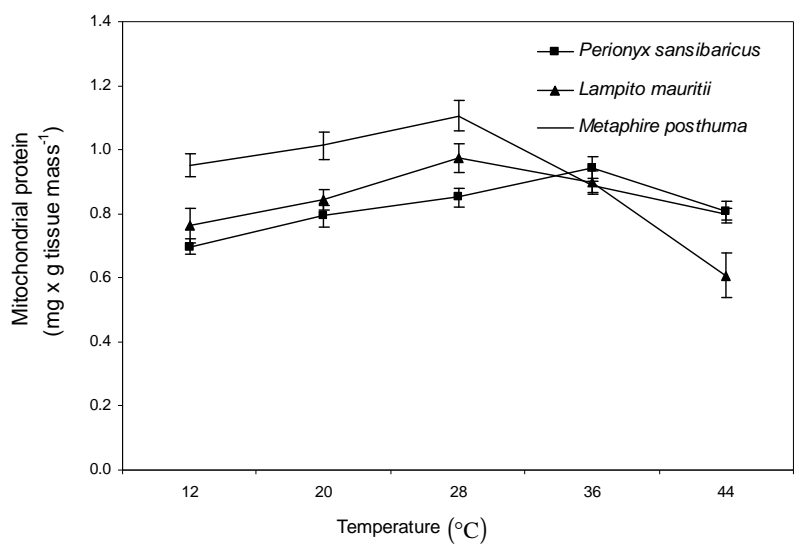

Figure 5 - Effects of temperature on mitochondrial protein content of different species of earthworms. 


\section{DISCUSSION}

Most prominent changes in cMDH specific activity were observed in P.sansibaricus, followed by L.mauritii and M.posthuma. The cMDH specific activity of $M$. posthuma was much lower than that of $P$. sansibaricus and $L$. mauritii. It could be because of endogeic nature of the earthworm. In case of $\mathrm{mMDH}$, the maximum variations were observed in L.mauritii and minimum in M.posthuma. The degree of variations in the protein contents of cytoplasmic and mitochondrial fractions remained more or less constant (i.e., $26-41 \%$ change) with respect to the changes in surrounding temperatures in all the three earthworm species. Earthworms have a wide biogeographic distribution extending from the tropical habitats to latitudes as high as the subarctic. Different species of earthworms might have evolved different aerobic and anaerobic metabolic strategies to adapt to temperature alterations. Many earthworms respond to low temperature by adjusting capacities of enzymes from energy metabolism. Temperature-induced variations in the enzymatic activities may contribute to the compensatory changes at cellular metabolic level. There is an exponential relationship between the ambient temperature and metabolic rate of animal to some extent. Temperature may be an important factor related to the metabolism of earthworms (Hochachka and Somero, 1984; Gracey et al., 1996). Crockett et al. (2001) examined the activities of enzymes from glycolysis and central oxidative pathways as well as fluidity and phospholipid fatty acid composition of mitochondrial membranes prepared from the body wall of the temperate oligochaete Lumbricus terrestris to find out the changes in the enzymatic capacities and physical properties of membrane after exposure to low temperatures. They found no compensation in the central pathways of oxidative metabolism after a month acclimation to 5 and $15^{\circ} \mathrm{C}$. However, the activity of enzyme pyruvate kinase was elevated after acclimation to $5^{\circ} \mathrm{C}$. Mitochondrial membranes displayed inverse compensation with respect to temperature (membranes from $5^{\circ} \mathrm{C}$ animals were more orderly arranged than membranes from $15^{\circ} \mathrm{C}$ ) suggesting maintenance of its routine metabolism at low temperatures in L.terrestris.
The general consensus is that if the animal could metabolically compensate in different regimes of temperature, then the activities of enzymes involved in energy metabolism remain higher at lower temperatures to partially offset reduction in reaction rates brought on by decreased kinetic energy of the reactants. However, there are species and enzyme specific differences in acclimation responses. It may also be possible that the external factor such as the temperature might be influencing the concentration of metabolic enzymes and protein by affecting the expression of genes. The present observation could be compared with the fact that the activity of pyruvate kinase and cytochrome-c oxidase was elevated after acclimation to $5^{\circ} \mathrm{C}$. However, hexokinase and citrate synthase showed no alteration with the temperature change (Crockett et al., 2001). The effects of temperature on the lipid composition and oxygen consumption (Petersen and Holmstrup, 2000) in earthworms has also been documented. Pörtner (2002) documented that the enzymes from cold living ectotherms often functioned more effectively at lower temperatures than homologous enzymes from the warm-living ectotherm. The present report advocates the compensatory changes in the capacity of enzymes involved in the aerobic and anaerobic respiratory metabolism. The enzymatic and protein changes were associated with the ecophysiological conditions of different categories of the earthworms.

\section{REFERENCES}

Abe, A.S. (1985), Oxygen uptake of active and aestivation earthworm Glossoscolex paulistus (Oligochaeta, Glossoscolecidae). Comp. Biochem. Physiol. 81A, 63-66

Arnould, J.P.Y., Green, J.A. and Rawlins, D.R. (2001), Fasting metabolism in Antarctic fur seal (Arctocephalus gazelle) pups. Comp. Biol. Physiol. 129A, 829-841

Childress, J. J. and Somero, G. N. (1990), Metabolic scaling: A new perspective based on scaling of glycolytic enzyme activities. Am. Zool., 30, 217-229

Crockett,E.L., Dougherty,B.E. and McNamer,A.N. (2001), Effects of acclimation temperature on enzymatic capacities and mitochondrial membranes from the bodywall of the earthworm Lumbricus terrestris. Comp.Biochem.Physiol. 130, 419-426 
Eshky, A.A., Taylor, A.C. and Atkinson, R.J.A. (1996), The effects of temperature on aspects of respiratory physiology of the semi-terrestrial crab, Uca inverse (Hoffmann) and Metopograpsus messor (Forskal) from Red Sea. Comp. Biochem. Physiol. 114A, 297204

Fan, Q., Wu, C., Li, L., Fan, R., Wu, C., Hou, Q. and He, R. (2001), Some features of intestinal absorption of intact fibrinolytic enzyme III-1 from Lumbricus rubillus. Biochem. Biophy. Acta (BBA)- General subjects, 1526, 286-292

Fitzpatrick,L.C., Goven,A.J., Earle,B., Rodrigues,J., Briceno,J., Venables,B.J. (1987), Thermal acclimation, preference and effects on $\mathrm{Vo}_{2}$ in the earthworm Lumbricus terrestris. Comp. Biochem. Physiol. 87A, 1015-1016

Foster, G.D. and Moon, T.W. (1986), Cortisol and liver metabolism of immature Americans eel, Anguilla rostrata (LeSueur). Fish physiol. Biochem. 1, 113124

Gracey,A.Y., Logue,J., Tiku,P.E., Cossins,A.R. (1996), Adaptation of biological membrances to temperature: biophysical perspectives and molecular mechanisms. In: Animals and Temperature: Phenotypic and Evolutionary Adaptation. Johnston, I.A., Bennett, A.F. (Eds.), Cambridge University Press, Cambridge. pp. 1-21

Hazel,J.R. (1995), Thermal adaptation in biological membrances: Is homeoviscous adaptation the explanation? Ann. Rev. Physiol. 57, 19-42

Hochachka,P.W. and Somero,G.N. (1984), Biochemical Adaptation. Princeton University Press, Princeton. pp-521

Holmstrup,M. and Petersen,B.F. (1997), Freezetolerance in the subarctic earthworm Eisenia nordenskioeldi (Eisen). Cryo-Letters 18, 153-156

Holmstrup,M. and Zachariassen, K.E. (1996), Physiology of cold hardiness in earthworms. Comp. Biochem. Physiol. 115, 91-101

Holmstrup,M., Costonzo,J.P. and Lee,R.E. (1999), Cryoprotective and osmotic response to cold acclimation and freezing in freeze-tolerant and freeze-intolerant earthworms. J. Comp. Physiol., 169, 207-214

Horecker,B.L. and Kornberg,A. (1948), The extinction coefficients of the reduced band of pyridine nucleotides. J.Bio.Chem. 175, 385-390

Lavelle, P., Barois, I., Martin, A., Zaidi, Z. and Schaefer, R. (1989), Management of earthworm populations in agroecosystems: A possible way to maintain soil quality? In : Ecology of Arable Land. (Eds.) 109-122pp. Kluwer, The Netherlands
Lavelle,P. (1983), The structure of earthworm communities. In: Earthworm Ecology-from Darwin to Vermiculture (J.E. Satchell, ed.), Chapman and Hall, London, England. pp. 449-466

Lee,K.E. (1985), Earthworms: Their Ecology and Relationship with Soils and Land Use. Academic Press, London, 411 p.

Lowery, O.H., Rosebrough, N.J., Farr,A.L. and Randall, A.J. (1951), Protien measurement with the folin phenol reagent. J.Bio.Chem. 193, 265-275

Magnum, C.P. (1978), Temperature adaptation. In: Physiology of annelids (Mill, P.J., Ed.) London, England: Academic Press. pp. 447-478

Mazantzeva,G.P. (1985), Soil fauna and soil fertility. In: Proc. $9^{\text {th }}$ Intl. Colloq. Soil Zool. (Ed., B.R. Striganova), Nauka, Moscow, pp. 139-143

Petersen, S.O. and Holmstrup, M. (2000), Temperature effects on lipid composition of the earthworms Lumbricus rubellus and Eisenia nordenskioeldi. Soil. Boil. Biochem., 32, 1787-1791

Pomert, G. M. and Zarrow M. P. (1936), Effect of temperature on the respiration of the earthworm. Proc. Natl. Acad. Sci. USA. 22, 270-272

Pörtner,H.O. (2002), Climatic Variations and the physiological basis of temperature dependent biogeography: systematic to molecular hierarchy of thermal tolerance in animals. Comp. Biochem. Physiol. 132, 739-761

Saroja, K. (1961), Seasonal acclimatization of oxygen consumption to temperature in a tropical poikilotherm, the earthworm, Megascolex mauritii. Nature. 190, 930-931

Schwantes, M.L.B. and Schwantes, A.R. (1982) Adaptative features of Ectothermic enzymes-I temperature effects on the $\mathrm{MDH}$ from a temperate fish, Leiostomus xanthurus. Comp. Biochem. Physiol. 72, 49-58

Tripathi, G. and Bhardwaj, P. (2004a), Seasonal changes in population of some selected earthworm species and soil nutrients in cultivated agroecosystem. J.Environ.Biol., 25 (2), 221-226

Tripathi, G. and Bhardwaj, P. (2004b), Comparative studies on biomass production, life cycles and composting efficiency of Eisenia fetida (Savigny) and Lampito mauritii (Kinberg). Bioresource Technology, 92, 275-283

Well, N.G. (1980), Invertebrate respiration. The institution of biology's studies in biology. No. 127. London, England: Edward Arnold. p. 42-55

Received: May 21, 2009; Revised: September 01, 2009; Accepted: August 18, 2010. 